\section{Analisis Patron Klien Terhadap Kemenangan Partai Golkar Kabupaten Tanah Datar Sejak Reformasi}

\section{Irvan Ansyari*}

Universitas Diponegoro, Semarang, Jawa Tengah, Indonesia Irvana186@gmail.com

\section{Priyatno Harsasto}

Universitas Diponegoro, Semarang, Jawa Tengah, Indonesia hang@yahoo.com

\section{Fitriyah}

Universitas Diponegoro, Semarang, Jawa Tengah, Indonesia fitriyasemarang@yahoo.co.id
Indonesian Journal of Religion and Society, 2019, Vol. 01 (01), 12-23

(C) The Journal, 2019

www.journal.lasigo.org/index.php/IJRS

Layles Journal

Article History

Received : March, $3^{\text {rd }} 2019$

Revised: Mei, $5^{\text {th }} 2019$

Accepted : Mei $6^{\text {th }} 2019$

\begin{abstract}
Golkar as the dominance party in Tanah Datar is an interesting case study for Islamic values area in their customs. This shows the weak political flow in Tanah Datar. The political dominance of Golkar has occurred since the New Order era until the collapse of the new order power that showed by the winner of regional head elections (Bupati), Golkar in DPRD and the power of the Golkar Party. This study used qualitative descriptive through in-depth interviews with selected informants through purposive sampling. The results indicate that the patron client relationship occurs between the Golkar Party cadres and the supporting community. This is indicated by a very wide and structured Golkar Party network starting from the Regent, adat institutions, religious leaders, businessmen, cultural figures and Wali Nagari.
\end{abstract}

Keywords: political party; party of Golkar; political domination; political clientism

\begin{abstract}
ABSTRAK
Dominasi Partai Golkar di Kabupaten Tanah Datar adalah sebuah kajian yang menarik di daerah dengan nilai keislaman dan adat-istiadat yang tinggi. Partai Golkar berhasil menjadi partai dominan yang menunjukkan lemahnya politik aliran. Partai Golkar telah mendominasi di Tanah Datar sejak Era Orde Baru hingga runtuhnya kekuasaan Orde Baru yang ditunjukkan oleh pemenang pemilihan Kepala Daerah (Bupati) yang dicalonkan, perolehan suara di DPRD Tanah datar, serta kekuasaan Partai Golkar yang membentuk jaringan hingga tingkat Nagari. Penelitian dilakukan dengan menggunakan pendektan deskriptif melalui proses pengumpulan data melalui wawancara mendalam dengan informan yang dipilih secara purposive. Hasil penelitian menunjukkan bahwa hubungan patron klien terjadi antara antara kader Partai Golkar dengan masyarakat pendukung. Hal ini ditunjukkan oleh jaringan Partai Golkar yang sangat luas dan terstruktur mulai dari Bupati, lembaga adat, tokoh agama, pengusaha, budayawan hingga Wali Nagari.
\end{abstract}

Kata Kunci: partai politik; partai Golkar; dominiasi politik; klientisme politik

${ }^{*}$ Corresponding Author

Name : Irvan Ansyari

Email : irvana186@gmail.com 


\section{Pendahuluan}

Pemilihan umum atau sering dikenal luas dengan Pemilu merupakan salah satu pilar dan poin penting dalam sebuah negara Demokratis. Dalam negara demokratis, kedaulatan tertinggi berada pada rakyat, hal ini terlihat jelas melalui pengertian dari demokrasi yang berarti pemerintahan dari rakyat, oleh rakyat dan untuk rakyat (Budiarjo, 2008). Rakyat memilih seorang pemimpin untuk melakukan dan melaksanakan perubahan bagi tempat dan daerah yang dipimpin. Hal ini sejalan dengan harapan masyarakat bahwa pemimpin harus mampu menjalankan keinginan rakyat. Masyarakat di Kabupaten Tanah Datar, Sumatera Barat mayoritas dihuni oleh etnis Minangkabau. Etnis Minangkabau adalah salah satu etnis yang unik di Indonesia dengan sistem kekerabatan matrilineal, suatu adat masyarakat mengatur alur keturunan berasal dari pihak ibu. Kata matrilineal seringkali disamakan dengan matriarkhat atau matriarkhi, meskipun makna berbeda. Matrilineal berasal dari dua kata bahasa Latin, yaitu mater yang berarti ibu, dan linea yang berarti garis. Matrilineal berarti mengikuti garis keturunan yang ditarik dari pihak ibu. Sistem garis keturunan matrilineal disebut sebagai suatu adat yang langka karena hanya beberapa suku saja yang menganutnya seperti Suku Indian di Apache Barat, Suku Khasi di Meghalayat, Suku Nakhi di provinsi Sichuan dan Yunnan Tiongkok dan Suku Minangkabau di Sumatera Barat.

Beberapa kebijakan pemerintah dalam mencukupi ketersediaan pangan yang dilakukan semasa Orde Baru hingga sekarang ini menjadi salah satu bentuk kegagalan pemerintah dalam mempertahankan kearifan lokal masyarakat. Beberapa kebijakan pemerintah seperti beras untuk rumah tangga miskin (raskin), pangan miskin, dan lain-lain, merupakan program yang dinilai salah. Hal tersebut mengubah pola pikir masyarakat terhadap pola makan sehari-hari. Masyarakat menilai beras sebagai bahan makanan yang paling sempurna dibandingkan dengan bahan makanan lainnya. Padahal tidak semua daerah di Indonesia mampu ditanami benih padi seperti beberapa daerah di Kabupaten Gunung Kidul, Maluku Tenggara dan sebagainya.

Homogenitas masyarakat di kabupaten Tanah Datar ternyata tidak terlalu berpengaruh terhadap perilaku memilih. Masyarakat memilih partai yang sesuai dengan basis agama maupun kesukuan masyarakat Minangkabau. Walaupun dari tiga pemilihan, partai-partai yang berbasiskan Islam seperti PKS dan PAN selalu menduduki top 4, tapi tetap saja tiga pemilu tersebut dimenangkan oleh partai yang bukan partai berbasis Islam. Partai pemenang pemilu tersebut adalah partai Golkar. Kegagalan partai-partai berbasis Islam merupakan agama mayoritas suku Minangkabau dalam pemilu legislatif sejak tahun 1999. Pemilihan umum legislatif tersebut diwarnai oleh dominasi partai Golkar yang bukan merupakan partai berideologi dan berlandaskan Islam seperti adat istiadat dan kesukuan pada masyarakat Minangkabau.

Dalam pemilihan umum khususnya di Kabupaten Tanah datar, dari tiga kali Pemilihan Umum langsung legislatif di Kabupaten Tanah Datar selalu memenangkan partai yang sama yaitu golkar. Pemilih tidak terganggu dengan isu-isu negatif dan pemilih partai Demokrat (2009) dan Partai Demokrasi Indonesia Perjuangan (2014) yang pada tahuntahun tersebut memenangkan pemilu legislatif secara nasional. Pemilih juga tidak terpengaruh oleh pola kampanye politik melalui berbagai media iklan (Firdaus, 2013) sebagaimana lazimnya kampanye politik dalam siste Pemilu Indonesia. Kuatnya dukungan terhadap partai Golkar di Kabupaten Tanah Datar juga terbukti pada pemilihan Kepala Daerah (Bupati) yang dimenangkan dua periode oleh calon yang sama dan didukung oleh golkar sebagai partai politiknya

Kemenangan Partai Golkar terjadi secara konsisten. Bahkan ketika runtuhnya rezim orde baru yang menjadikannya sebagai alat kekuasaan, partai Golkar tetap menjadi Partai dominan. Hal ini menjadi sesuatu yang menarik mengingat secara nasional terjadinya pergantian rezim mengakibatkan muncul dan menjamurnya partai-partai politik baru. Dampaknya terlihat jelas, kekuatan Partai penguasa khususnya Golkar akan cenderung berkurang, pemilu 1999 menjadi bukti merosotnya kekuatan Golkar secara nasional. Hal ini tidak terjadi di Kabupaten Tanah Datar, bahkan dalam pemilihan umum kepala daerah maupun pemilihan umum legislatif Partai Golkar tetap menjadi pemenang mutlak. Pada pemilihan umum 2014, Partai Golkar masih menjadi partai penguasa di Kabupaten Tanah 
Datar. Fenomena tersebut merupakan fokus penelitian dan analisis lebih dalam tentang kemenangan partai Golkar di Kabupaten Tanah Datar yang terjadi sejak bergulirnya era reformasi.

\section{Kerangka Teori}

\subsection{Partai Politik}

Partai politik berangkat dari anggapan bahwa dengan membentuk wadah organisasi mereka bisa menyatukan orang-orang yang mempunyai pikiran serupa sehingga pikiran dan orientasi mereka bisa dikonsolidasikan. Wadah tersebut meningkatkan pengaruh lebih besar dalam pembuatan dan pelaksanaan keputusan. Secara umum, partai politik merupakan suatu kelompok terorganisir yang anggota-anggotanya mempunyai orientasi, nilai-nilai dan cita-cita yang sama. Tujuan kelompok tersebut adalah untuk memperoleh kekusaan politik dengan cara konstitusional (Firmanzah, 2008). Dalam hal kekuasaan, partai politik akan berusaha untuk memberi pengaruh maupun hegemoni di suatu daerah. Jadi, partai politik bisa menjadi penentu maupun memberi arah kebijakan publik suatu daerah.

Menurut Firmanzah (2008) dalam buku Mengelola Partai Politik, ada beberapa positioning politik yang sangat penting untuk kemenangan suatu partai poltik dalam pemilihan umum yakni analisis pemilih, analisis pesaing, dan analisis tren yang sedang berkembang di masyarakat. Analisis pemilih terdiri dari ikatan rasional, tradisionalitas pemilih, mitos, simbol, garis primordialisme, dan kepuasan pemilih. Sementara untuk menganalisis pesaing terdiri dari strategi politik pesaing dan strategi lobi politik. Untuk menganalisis tren yang sedang berkembang di masyarakat, diperlukan positioning politik, harus mengetahui budaya masyarakat setempat (Asfar, 2004).

\subsection{Demokrasi Patron Klien}

Patron berasal dari bahasa latin yaitu patronas atau bermakna bangsawan, sedangkan klien berasal dari kata cliens yang berarti pengikut (Jones, 2003). Dalam bahasa Spanyol, istilah patron secara etimologis berarti seseorang yang memiliki kekuasaan, status, wewenang dan pengaruh besar. Sedangkan klien brarti bawahan atau orang yang diperintah (Kurniadi, 2012).

Selanjutnya, pola hubungan patron klien merupakan aliansi dari dua kelompok komunitas atau individu yang tidak sederajat, baik dari segi status, kekuasaan, maupun penghasilan, sehingga menempatkan klien dalam kedudukan yang lebih rendah (inferior) dan patron menempatkan klien dalam kedudukan yang lebih tinggi (superior) (Gaffar \& Dkk, 1998). Pola relasi seperti ini di Indonesia lazim disebut sebagai hubungan bapak-anak buah, dimana bapak mengumpulkan kekuasaan dan pengaruhnya dengan cara membangun keluarga besar. Setelah itu, bapak harus siap menyebarluaskan tanggung jawabnya dan menjalin hubungan dengan anak buah secara personal, tidak ideologis dan tidak politis (Alkhudri, 2014).

Menurut Scott, hubungan patron klien adalah hubungan antara dua orang yang sebagian besar melibatkan hubungan instrumental diantara seseorang yang kedudukannya lebih tinggi secara sosial dan ekonomi (patron) dengan menggunakan pengaruh dan sumberdaya yang dimilikinya. Tujuan hubungan tersebut adalah untuk memberikan perlindungan kepada orang yang lebih rendah kedudukannya (klien), yang pada gilirannya harus memberikan dukungan atau bantuan jasa pribadi terhadap patron (Scott, 1972).

Sementara itu Pelras juga menguraikan arti dari hubungan patron dan klien. Menurutnya, patron berasal dari kata patronus yang bermakna bangsawan, sementara klien berasal dari kata clien yang berarti pengikut (Nugroho et al., 2011). Jika ditambahkan dengan kata "hubungan" maka hubungan patron klien dapat diartikan sebagai hubungan yang tidak setara yang berlangsung antara seorang bangsawan dengan sejumlah pengikut jelata berdasarkan pertukaran barang dan jasa yang didalamnya. Ketergantungan klien terhadap patron dibalas dengan dukungan perlindungan patron terhadap klien. 
Burke mendefinisikan patronase sebagai sistem politik yang berlandaskan pada hubungan pribadi antara pihak-pihak yang tidak setara antara pimpinan (patron) dan pengikutnya (klien) (Burke, 2001). Masing-masing pihak mempunyai sesuatu untuk ditawarkan. Klien menawarkan dukungan politik dan penghormatan kepada patron yang ditampilkan dalam berbagai bentuk simbolis (sikap kepatuhan, bahasa yang hormat, hadiah dan lain-lain). Di sisi lain, patron menawarkan kebaikan, pekerjaan dan perlindungan kepada kliennya (Scott, 1972).

Menurut Levinson dan Embe, hubungan patron-klien yang terlihat sebagai suatu fakta sosial-kultural dan hanya didasarkan pada perjanjian informal menjadi pembungkus yang halus dari hubungan sosial, politik dan ekonomi yang diwarnai ketidaksetaraan (Ember \& Ember, 2001). Padahal, dalam hubungan yang diwarnai ketidaksetaraan, maka peluang untuk terjadinya eksploitasi menjadi sangat besar.

Unsur utama dalam hubungan patron-klien adalah hal yang diberikan salah satu pihak merupakan barang ataupun jasa yang berharga di pihak lain. Dengan demikian, pihak penerima akan memiliki kewajiban untuk membalas pemberian pihak pertama sehingga terjadilah hubungan timbal-balik yang mutualisme (Misrina, 2010). Hubungan patron-klien berbeda dengan pemaksaan ini disebabkan karena hubungan patron-klien merupakan wewenang formal yang didukung oleh norma-norma dalam masyarakat sehingga memungkinkan pihak klien melakukan penawaran atau menarik diri dari hubungan tersebut apabila yang diinginkan tidak sesuai (Surbakti, 2016).

Dalam hubungan patron klien, konsep ketidaksamaan (inequality) berbeda dengan konsep ketidakseimbangan (imbalance), karena pertukaran barang dan jasa yang diberkan tidak selalu sama dengan yang diterima. Namun, pertukaran bisa saja seimbang menurut kedua belah pihak. Yang menarik dalam hubungan ini adalah sering terjadi kesengajaan ketidak-seimbangan atau ketidaksamaan pertukaran oleh kedua belah pihak agar kontrak atau hubungan timbal balik tidak berhenti (Foster, 1990).

Scoott memberikan definisi bahwa ikatan patron klien didasarkan dan berfokus pada pertukaran tidak setara yang berlangsung antara kedua belah pihak, serta tidak didasarkan pada kriteria deskripsi (Scott, 1972). Oleh karena itu, pemberi modal berstatus sebagai patron. Scott memberikan contoh terhadap hasil temuannya dengan melihat hubungan timbal balik yang terjadi antara petani penggarap dengan pemilik lahan. Syarat menjadi seorang patron, pemilik lahan memanfaatkan modal yang dmilikinya untuk merekrut klien. Patron memberikan pekerjaan untuk menggarap lahan yang dimiliki patron. Patron juga tidak segan-segan melindungi kliennya dengan memberikan jaminan ketika paceklik maupun melindungi para penggarap lahan terhadap makelar. Dari perlindungan inilah patron mengharapkan hadiah dari kliennya, tergantung kebutuhan patron. Hubungan patron klien merupakan hubungan yang antara dua pihak yang menyangkut persahabatan, dimana seorang individu dengan status sosial ekonomi yang lebih tinggi (patron) menggunakan pengaruh dan sumber-sumber yang dimilikinya untuk memberikan perlindungan dan atau keuntungan bagi seseorang yang statusnya lebih rendah (klien), dan sebaliknya klien membalas dengan memberikan dukungan dan bantuan secara umum termasuk pelayanan pribadi kepada patron. Dalam hubungan ini, pertukaran tersebut merupakan jalinan yang rumit dan berkelanjutan yang akan terhapus dalam jangka panjang. Imbalan yang diberikan klien bukan imbalan berupa materi melainkan dalam bentuk lainnya.

Patron tidak akan mengharapkan materi atau uang dari klien tapi mengharapkan imbalan lain yang dibutuhkan patron. Dalam memahami hubungan patron klien, ada satu hal penting yang mendasari hubungan ini. Hubungan patron klien berawal dari adanya pemberian barang atau jasa dalam berbagai bentuk yang sangat berguna atau diperlukan oleh salah satu pihak, sementara bagi pihak yang menerima barang atau jasa tersebut berkewajiban untuk membalas barang tersebut (Scott, 1972). Scott memberikan contoh terhadap hasil temuannya dengan melihat hubungan timbal balik yang terjadi antara petani penggarap dengan pemilik lahan. Dalam upaya menjadi patron, pemilik lahan memanfaatkan modal yang dimiliki untuk mencari klien. Patron memberikan pekerjaan 
berupa menggarap lahan yang dimiliki patron. Patron juga tidak segan-segan melindungi kliennya dengan memberikan jaminan ketika paceklik tiba maupun melindungi para penggarap lahan terhadap makelar. Dari perlindungan inilah patron mengharapkan hadiah dari kliennya berdasarkan kebutuhan patron.

\section{Metode Penelitian}

Penelitian menggunakan metode penelitian deskriptif kualitatif. Penelitian kualitatif tidak hanya bertujuan mencari sebab akibat tetapi fokus pada upaya memahami situasi tertentu serta berbagai keunikan yang terdapat dalam individu, kelompok, masyarakat atau organisasi. Tipe penelitian menggunakan analisis deskriptif yaitu tipe penelitian yang bermaksud untuk mencari fakta dengan interpretasi data yang tepat sehingga dapat membuat deskripsi, gambaran atau lukisan yang secara sitematis, faktual dan akurat mengenai fenomena-fenomena yang diselidiki. Penelitian ini menggambarkan tentang sistem patron klien berperan sangat besar dalam kemenangan Partai Golkar di Kabupaten Tanah Datar. Teknik analisa data dalam penelitian adalah menggunakan jenis analisis data deskriptif-kualitatif yang dilakukan untuk memahami tanggapan informan dalam menarik suatu pernyataan yang mendukung dari pemahaman atas kejadian yang sebenarnya, kemudian dibuat pembahasan dan kesimpulan atas data hasil penelitian yang dinyatakan dengan tulisan, kata-kata atau kalimat (Hadari, 1995).

Penelitian ini menggunakan teknik purposive sampling atau pemilihan responden secara sengaja, yaitu beberapa responden yang mengerti tentang Partai Golkar di Kabupaten Tanah Datar dan beberapa responden di kalangan masyarakat biasa yang merasakan dampak dari kebijakan yang diambil oleh petinggi Partai Golkar di tingkat eksekutif maupun legislatif. Peneliti berusaha memilih sampel dari wakil-wakil di segala lapisan populasi yang terlibat langsung atau dianggap memiliki kemampuan dengan cermat sehingga relevan dengan rancangan penelitian. Dengan demikian, peneliti mengusahakan agar sampel tersebut memiliki representatif.

Narasumber yang diwawancara diantaranya pengurus Partai Golkar Kabupaten Tanah Datar, senior yang sudah berpengalaman di Partai Golkar sejak era orde baru, elit tradisional maupun elit formal yang berafiliasi dengan Partai Golkar, dan masyarakat yang pendukung Partai Golkar. Wawancara dilakukan secara mendalam untuk menemukan hubungan patronas antara elit Partai Golkar dengan masyarakat pendukung Partai di Kabupaten Tanah Datar. Selain itu, dokumen-dokumen seperti buku pemenangan pemilukada maupun pemilu legislatif dari Partai Golkar Kabupaten Tanah Datar juga dijadikan sumber data untuk mengidentifikasi elit yang berafiliasi dengan Partai maupun strategi yang digunakan oleh partai sebelum dilakukan wawancara mendalam dengan narasumber terpilih.

\section{Gambaran Umum Kabupaten Tanah Datar}

Kabupaten Tanah Datar merupakan salah satu kabupaten di provinsi Sumatera Barat dengan $0^{\circ} 27^{\prime} 12^{\prime \prime} \mathrm{LU} 100^{\circ} 35^{\prime} 38^{\prime \prime} \mathrm{BT}$. Kabupaten ini merupakan kabupaten terkecil kedua untuk luas wilayah di Sumatera Barat, yaitu $133.600 \mathrm{Ha}(1.336 \mathrm{~km} 2)$. Jumlah penduduk berdasarkan sensus pada tahun 2006 adalah 345.383 jiwa yang mendiami 14 kecamatan, 75 nagari, dan 395 jorong. Kabupaten Tanah Datar merupakan daerah agraris, lebih $70 \%$ penduduknya bekerja pada sektor pertanian, baik pertanian, tanaman pangan, perkebunan, perikanan, maupun peternakan.

Kabupaten Tanah Datar merupakan Tujuh Kabupaten Terbaik di Indonesia dari 400 kabupaten. Penghargaan ini diberikan pada tahun 2003 oleh Lembaga International Partnership dan Kedutaan Inggris. Lembaga Ilmu Pengetahuan Indonesia (LIPI) menobatkan Kabupaten Tanah Datar sebagai satu dari empat daerah paling berprestasi dan berhasil melaksanakan otonomi daerah. Selain itu, melalui hasil survei IPK (Indeks Persepsi Korupsi) pada tahun 2006, Kota atau Kabupaten yang dipilih untuk pelaksanaan in-depth analysis adalah 5 kota dengan IPK tertinggi dan 5 kota dengan IPK terendah. Kota-kota tersebut adalah: 1. Palangkaraya (6.61), 2. Kabupaten Wonosobo (5.66), 3.Kota Pare-pare (5.66), 4.Kabupaten Tanah Datar (5.66), 5.Kota Yogyakarta (5.59), 6.Kota Cilegon (3.85), 7. Kota Denpasar (3.67), 8.Kota Gorontalo (3.44), 9.Kota Mataram (3.42), 10.Kota Maumere (3.22). Kabupaten Tanah Datar merupakan salah satu kabupaten dengan Indeks Persepsi 
Korupsi tertinggi, sejajar dengan Kabupaten Wonosobo dan Kota Pare-pare dengan indeks 5.66. Sesuai dengan hasil survei ini, Kabupaten Tanah Datar dinilai sebagai salah satu kabupaten terbersih dari praktek-praktek korupsi di antara 32 kota dan kabupaten yang diteliti dalam IPK 2006.

\section{Dominasi Partai Golkar di Tanah Datar}

\subsection{Analisis Positioning Politik Partai Golkar}

Mayoritas masyarakat Kabupaten Tanah Datar adalah orang Minangkabau asli dan beragama Islam, dimana Islam memang identik dengan adat istiadat masyarakat Minangkabau. Golkar selalu menjadi partai penguasa dan partai-partai islam yang ada di Kabupaten Tanah Datar belum mampu menampik dominasi Golkar. Dari data Pemilu Legislatif di Kabupaten Tanah Datar, Partai Golkar mendominasi dan selalu menjadi pemenang dalam pemilihan umum. Beberapa teori menjelaskan bahwa kemenangan Partai politik dipengaruhi oleh kedekatan interpersonal antara pemilih dengan Partai Politik atau adanya politik aliran dari masing-masing pemilih.

Menurut Firmanzah (2008), ada beberapa indikator dalam menganalisis perilaku pemilih dalam pemilihan umum pada pemilihan umum legislatif maupun pemilihan umum presiden. Faktor-faktor tersebut yaitu ikatan rasional, tradisionalitas pemilih, mitos dan simbol, garis primordialisme, ikatan emosional dan kepuasan pemilih terhadap partai atau calon tersebut. Berdasarkan analisis dari Positioning Politik (Analisis Pemilih, Analisis Pesaing dan Tren Masyarakat), Golkar di Kabupaten Tanah Datar memang sangat menguasai tiga pokok penting dari Positioning Politik. Dari analisis pemilih misalnya, kaderkader Golkar sudah memiliki ikatan rasional yang kuat dengaan pemilih, mampu menyesuaikan diri dengan pemilih tradisional, dan kinerja kader-kader Golkar sudah mampu memuaskan pemilih, yang terbukti dari wawancaa-wawancara yang dilakukan dengan pemilih maupun dengan pengurus Partai.

Pesaing utama Partai Golkar di Kabupaten Tanah Datar adalah partai-partai Islam yang selalu bergantian menghuni posisi 2 sampai 4 dari tahun 2004. Hal tersebut disebabkan karena faktor kultural masyarakat Kabupaten Tanah Datar yang mayoritas beragama Islam dan bersuku Minang, ditambah lagi adat-istiadat masyarakat Minangkabau identik dengan Islam, tetapi inilah yang tidak mampu dimanfaatkan oleh partai-partai Islam, masyarakat menilai kinerja pemuka agama yang memang berafliasi politik ke Golkar lebih nyata daripada kader partai-partai Islam. Selain itu, pemuka Agama dari partai Golkar memang populer di mata masyarakat Kabupaten Tanah Datar. Dalam menghadapi masyarakat, kader-kader Golkar dinilai mampu menyesuaikan diri dengan lingkungannya dan dekat dengan masyarakat.

Salah satu faktor yang paling berperan dalam keberhasilan dan kemenangan Partai pada pemilihan umum adalah strategi dari internal partai. Strategi pemenangan pemilu adalah siasat dari para petinggi partai dalam pemenangan pemilihan umum legislatif. Dominasi Golkar di Kabupaten Tanah Datar bahkan sejak era Orde Baru tak lepas dari strategi Partai Politik untuk meraup simpati masyarakat di daerah yang bersangkutan khususnya di Kabupaten Tanah Datar.

Berdasarkan wawancara yang telah dilakukan dengan senior sekaligus wakil ketua DPD Partai Golkar, Bapak Drs Asri Rauf, mengatakan Golkar di Kabupaten Tanah Datar didukung oleh organisasi sayap yaitu: Pemuda Pancasila, Kelompok Tani, Angkatan Muda Partai Golkar (AMPG) dan Kesatuan Perempuan Partai Golkar (KPPG). Keberadaan organisasi sayap partai politik di Indonesia secara legal diakui dan dijamin negara dengan lahirnya UU Partai Politik baru yang telah disahkan DPR pada tanggal 6 Desember 2007, adanya organisasi sayap ini mempermudah Partai Golkar untuk melakukan hegemoni politik di Kabupaten Tanah Datar.

Perekrutan kader-kader berkualitas yang mampu menjadi panutan di masyarakat merupakan salah satu budaya yang dilakukan oleh Partai Golkar di Kabupaten Tanah Datar dalam rangka memuluskan jalannya untuk terus mendominasi di Kabupaten Tanah Datar. Berdasarkan wawancara dengan Bapak Drs Asri Rauf, Partai Golkar di Kabupaten Tanah Datar melakukan sistem rekrutmen dengan merekrut anggota partai di segala 
kelompok masyarakat mulai dari kelompok tani, agama, adat dan mengusahakan kaderkader partai Golkar disebar ke organisasi-organisasi massa termasuk organisasi independen sekalipun, sistem pengkaderan dilakukan dengan pendidikan politik bertingkat. Jadi, Partai Golkar menggunakan sistem kaderisasi dalam merekrut dan menghasilkan kader dengan karakteristik tertentu supaya dapat diukur keberhasilannya yang berlandasan hukum dalam undang-undang no. 2 Tahun 2008 tentang Partai Politik.

\subsection{Partai Golkar dan Relasi Patron Klien}

Hubungan Patron klien antara massa pemilih dengan elit partai adalah suatu hal yang lumrah terjadi. Hal tersebut dijelaskan oleh James C. Scott melalui penelitiannya, ikatan patron klien bersifat partikularistik dan kabur. Hubungan dibangun melalui proses yang panjang, secara turun-temurun dan berkelanjutan, hal inilah yang terjadi diantara kaderkader partai dengan masyarakat di Kabupaten Tanah Datar. Beberapa wawancara yang dilakukan dengan masyarakat dari berbagai kelas, maupun kader partai golkar yang sudah pernah mejabat di eksekutif dan legislatif mengindikasikan adanya hubungan patron klien.

Salah satu faktor pendukung hubungan patron klient menurut Scott adalah pelapisan status sosial masyarakat yang menyangkut antara perbedaan kedudukan antara orang yang mempunyai gelar dengan orang biasa. Di kabupaten Tanah Datar khususnya, orangorang yang mempunyai gelar Datuak atau niniak mamak adalah orang yang disegani dan dihormati oleh masyarakat. Gelar tersebut didapat dari musyawarah yang dilakukan oleh suku tertentu, dan setiap suku akan memilih pemimpin sukunya yang nantinya akan diberi gelar Datuak. Para pemimpin suku masing-masing yang tergolong menjadi anggota Kerapatan Adat Nagari (KAN) dan anggota KAN yang berada di Nagari akan memilih ketua Lembaga Kerapatan Adat Alam Minangkabau (LKAAM) Kabupaten Tanah Datar secara musyawarah. Jaringan Golkar pun tidak luput di dua lembaga ini, yang mana ketua KAN di tiap Nagari di dominasi oleh orang yang berafliasi politik ke Golkar, begitu juga dengan ketua Lembaga Kerapatan Adat Alam Minangkabau (LKAAM) Kabupaten Tanah Datar juga diketuai oleh kader Partai Golkar.

Dari data-data yang didapatkan dari wawancara dengan tokoh Golkar, masyarakat pendukung Partai Golkar, dan pengamat politik setempat dapat dikatakan bahwa peran sistem patron klien terutama ketokohan dari kader-kader Golkar sangatlah besar. Berikut adalah analisis peran patron-klien dalam dominasi Golkar di Kabupaten Tanah Datar:

\subsubsection{Pelapisan Status Sosial dan Kekuasaan di Tingkat Nagari}

Salah satu faktor pendukung hubungan patron klien menurut Scott adalah pelapisan status sosial masyarakat yang menyangkut antara perbedaan kedudukan antara orang yang mempunyai gelar dengan orang biasa. Di kabupaten Tanah Datar khususnya, orangorang yang mempunyai gelar Datuak atau niniak mamak adalah orang yang disegani dan dihormati oleh masyarakat. Gelar didapatkan dari musyawarah yang dilakukan oleh suku tertentu, dan setiap suku akan memilih pemimpin sukunya yang nantinya akan diberi gelar Datuak. Ketua LKAAM Kabupaten Tanah Datar akan dipilih secara musyawarah. Jaringan Golkar tidak luput di dua lembaga tersebut, ketua KAN di tiap Nagari di dominasi oleh orang yang berafliasikan politik ke Golkar, begitu juga dengan ketua LKAAM Kabupaten Tanah Datar juga diketuai oleh kader Partai Golkar.

\subsubsection{Pelapisan Kekayaaan}

Mayoritas masyarakat di Kabupaten Tanah Datar adalah petani. Mayoritas tokoh pengusaha di Kabupaten Tanah Datar berafliasi politik ke Golkar seperti Drs. Hendri N, MM yang merupakan politisi, budayawan, sekaligus pengusaha sukses di Batusangkar. Bapak Drs Hendri N MM dipandang masyarakat, terutama pemuda, sebagai orang yang dermawan dan sering memberi bantuan apabila ada acara-acara kepemudaan di tingkat Nagari. Kekayaan yang dimiliki oleh patron di Kabupaten Tanah Datar yang pernah menguntungkan masyarakat biasa yang diposisi klien walaupun tanpa embel-embel politik, secara tidak langsung akan menarik simpati dari klien yang akan membalasnya dengan 
jalan memilih partai atau afliasi politik dari orang yang pernah menolong dalam hal ekonomi.

\subsubsection{Keamanan dan Jaminan Sosial}

James C. Scot (1972) mengatakan bahwa kondisi ketidakpastian hidup masyarakat senantiasa membayangi kehidupan mereka, sehingga untuk mengantisipasi ketidakpastian pendapatan dan menjaga kelangsungan hidup, masyarakat mengembangkan jaringan hubungan tradisional yang bersifat patron-klien untuk menciptakan rasa aman sosial dan diharapkan menetralisasi kegundahan sosial nelayan karena tidak memperoleh penghasilan yang memadai untuk menopang kelangsungan hidup mereka secara normal. Pada umumnya, profesi masyarakat di Kabupaten Tanah datar merupakan petani yang membutuhkan adanya keamanan dan jaminan sosial, terutama kelangsungan hidup dan ekonomi. Hasil wawancara dengan masyarakat yang berprofesi sebagai petani menunjukkan bahwa adanya rasa aman secara ekonomi karena pernah ada orang berbenderakan Golkar yang memberikan bantuan untuk membuka usaha lain ketika terjadinya gagal panen, tetapi tanpa embel-embel politik. Hubungan tersebut menjadikan orang biasa (petani) di posisi klien memiliki hutang budi pada seorang pengusaha sekaligus pemuka adat di posisi patron. Jadi, walaupun hubungan pada saat itu tidak bernuansa politik, tetapi balas budi dari seorang klien berlangsung saat pesta demokrasi 5 tahunan (Pemilu).

\subsection{Jaringan Politik Partai Golkar}

Faktor penting kunci dari dominasi Golkar di Kabupaten Tanah Datar adalah jaringan partai. Dari data-data yang didapatkan, jaringan Golkar tersebar hingga ke pelosok Nagari di Kabupaten Tanah Datar, dari Wali Nagari (yang mayoritas memang berafliasi politik ke Golkar) hingga tokoh-tokoh pemuka adat seperti ketua LKAAM. Ketua LKAAM Kabupaten dipilih secara musyawarah oleh perwakilan Niniak Mamak dan Cadiak Pandai di setiap Nagari. Apabila ketua LKAAM adalah orang yang berafliasi politik ke Golkar, maka bukan tidak mungkin peran lembaga ini sangat sentral dalam meraup suara walaupun lembaga ini dianggap sebagai lembaga yang independen.

Dalam pemilu, Partai Golkar teridentifikasi mempunyai banyak tokoh yang memiliki jabatan strategis seperti ketua KONI, pengusaha, ketua PGRI, ulama setempat, ketua PKK, tokoh pemuda maupun Bupati yang sedang menjabat memiliki afiliasi politik dengan Partai Golkar (Buku Pemenangan Pemilu Golkar Kabupaten Tanah Datar). Hal ini menjadi salah satu faktor yang membuat Golkar tetap menjadi partai dominan di Kabupaten Tanah Datar. Tokoh-tokoh ini juga dianggap sebagai orang yang bisa menyesuaikan diri dan disegani dalam masyarakat.

"Kita memilih ya melihat dulu orang yang akan kita pilih, saya memilih golkar dari dulu karena memang orang-orangnya bisa menyesuaikan diri dengan masyarakat kecil seperti kami dan tidak sombong. Yang banyak bantu masyarakat disini ya orang Golkar, misal ada musibah mereka cepat datang, misal ada acara pemuda, mereka menyumbang, ada baralek, mereka hadir. Mereka tidak pernah menyuruh kami memilih Golkar, tetapi kami punya utang budi, kami segan sama mereka. Mereka itu datang ke sini tidak pas musim pemilu saja, selalu ada untuk masyarakat saat dibutuhkan" (wawancara dengan pendukung Partai Golkar)

Dari wawancara dengan salah seorang pendukung Partai Golkar tersebut, terlihat adanya hubungan atau relasi yang sifatnya partikularistik dan kabur, masyarakat secara tidak sadar sudah memilki hubungan patron klien dengan elit partai golkar di Kabupaten Tanah Datar. Hal ini terjadi sejak dulu hingga sekarang.

Selain tokoh masyarakat, Golkar juga mempunyai afiliasi politik dengan banyak walinagari di Kabupaten Tanah Datar. Sebanyak 50 dari 75 walinagari di seluruh Kabupaten Tanah Datar mempunyai afiliasi politik yang kuat dengan Partai Golkar (Buku Pemenangan Pemilu Partai Golkar Kab Tanah Datar 2014). Jabatan sebagai walinagari 
adalah jabatan yang strategis untuk dekat dengan masyarakat, karena Nagari merupakan unit pemerintahan terendah. Tidak mengherankan jabatan ini banyak digunakan sebagai batu loncatan karir politik seseorang sebelum terjun ke dunia politik, misalnya mencalonkan diri sebagai anggota legislatif. Pada umumnya, orang yang sudah berpengalaman sebagai walinagari akan mudah meraup suara dari masyarakat pendukungnya, karena elektabilitas ataupun tingkat kepopuleran dalam masyarakat sudah relatif tinggi. Hubungan kemenangan Golkar dengan hal ini sangatlah kuat karena walinagari adalah jabatan yang cukup disegani oleh masyarakat di tingkat grassroot. Masyarakat di tingkatan ini cenderung ikut dengan instruksi atau himbauan pemimpin mereka, atau bahkan masyarakat juga akan mengikuti perilaku politik dari pemimpin.

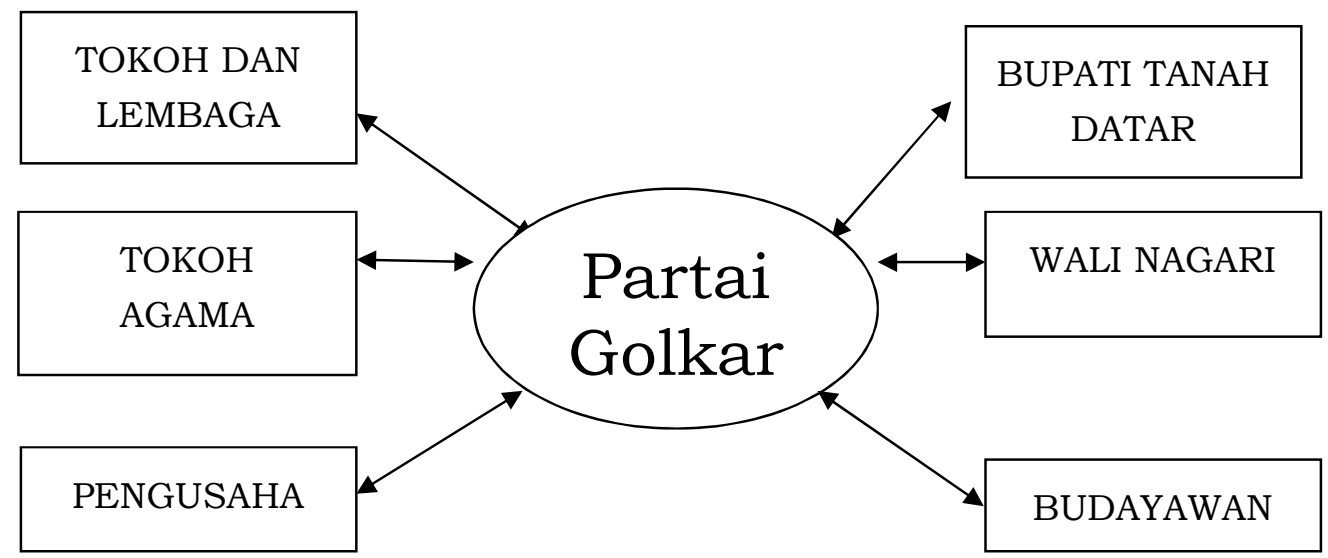

Gambar 1. Peta Kekuasaan Golkar di Kabupaten Tanah Datar Sumber: Hasil Penelitian

Berdasarkan peta kekuasaan Golkar, semakin menjelaskan peran dominasi Golkar dipengaruhi oleh peran jaringan kekuasaan yang didominasi oleh kader-kader Golkar, mulai dari tokoh adat, pemuka agama, pengusaha, budayawan, dan Wali Nagari. Teori patron klien, khususnya interaksi antara elit partai (patron) dengan massa pendukung (klien) sangat besar. Para elit atau pemimpin setingkat Nagari adalah pemimpin yang secara psikologis dan emosional dekat dengan masyarakat. Elit atau tokoh Nagari adalah orang yang paling mudah untuk mendapatkan simpati masyarakat, apabila elit atau tokoh ini memiliki modal sosial yang pernah menguntungkan masyarakat secara moril maupun ekonomi. Masyarakat akan menaruh simpati. Hal tersebut adalah keuntungan bagi Partai yang merupakan afliasi politik dari tokoh ataupun elit tersebut. Hal inilah yang terjadi di Kabupaten Tanah Datar, tokoh-tokoh Golkar yang ada di tingkat Nagari dianggap mampu mendapatkan simpati masyarakat. Jaringan Golkar menguasai seluruh elit ketokohan hingga tingkat Nagari di Kabupaten Tanah Datar. Selain itu, program-program Partai Golkar juga memiliki hasil yang nyata dengan diterbitkannya beberapa Perda oleh pemerintah daerah. Jadi, hal ini tidak lepas dari manuver dan suara fraksi Golkar di Parlemen Kabupaten Tanah Datar.

Dominasi dan kemenangan Golkar di Kabupaten Tanah Datar menjelaskan bahwa tokoh atau elit sangat penting dalam internal organisasi Partai Politik. Popularitas, intelektualitas, atau modal adalah komponen pendukung yang sangat vital bagi tokoh-tokoh tersebut. Kemampuan tersebut akan memudahkan Patron (tokoh) dalam memberi pengaruhnya ke klien (masyarakat pemilih). Selain itu, dominasi Golkar di Kabupaten Tanah Datar juga membuktikan tidak adanya politik aliran di ranah Minang seperti yang terjadi di pulau Jawa yang mana pemilih sangat identik dengan aliran politiknya yang melibatkan agama maupun profesi. 


\section{Hubungan Patron Klien Dalam Sistem Politik Partai Golkar Tanah Datar}

Dominasi Partai Golkar di Kabupaten Tanah Datar terjadi ketika Indonesia sudah memasuki era reformasi, dimana banyak muncul partai-partai baru. Ketika di daerah lain maupun di Nasional terjadi kemerosotan hegemoni kekuasaan partai Golkar, tetapi hal tersebut tidak terjadi di Kabupaten Tanah Datar. Beberapa faktor yang menjadi penentu dominasi maupun kemenangan Partai Golkar adalah afiliasi politik Partai dengan tokohtokoh berpengaruh di daerah, mulai dari mantan bupati, pengusaha, tokoh pemuda, walinagari yang berada di tingkat pemerintahan terendah. Afiliasi terjadi sejak era orde baru, dan berlanjut pasca reformasi. Tokoh-tokoh yang berpengaruh menjalin hubungan yang kuat dengan masyarakat di tingkat grassroot. Dari hasil penelitian dan wawancara dengan beberapa tokoh maupun masyarakat, antara tokoh yang merupakan kader maupun afiliasi politik Partai Golkar membentuk hubungan patron klien dengan masyarakat. Hubungan tersebut adalah semacam simbiosis mutualisme yang saling menguntungkan kedua belah pihak. Pada umumnya pihak klien adalah masyarakat pada tingkatan grassroot maupun diatasnya. Pihak tersebut diuntungkan secara sosial maupun ekonomi oleh tokoh-tokoh politik atau sebagai patron. Hubungan terjalin secara berkelanjutan, sehingga masyarakat yang diuntungkan sudah bersimpati dengan tokoh-tokoh Golkar yang membantu maupun memperhatikan mereka baik secara sosial maupun ekonomi.

Berdasarkan analisa perilaku memilih masyarakat yang merujuk pada teori positioning politik dari Firmanzah (2008), analisis berfokus pada pesaing, pemilih, dan tren masyarakat. Partai golkar di Kabupaten Tanah Datar menguasai semua aspek tersebut, mengetahui kelemahan partai-partai pesaingnya, khususnya partai-partai islam yang merupakan pesaing utama Golkar di Kabupaten Tanah Datar. Selain itu, Partai Golkar juga menguasai isu-isu yang berkembang di masyarakat sehingga bisa menyesuaikan dengan keadaan dan melanjutkan hubungan patron klien dengan masyarakat di tingkat grassroot.

Kunci dominasi Partai Golkar di Kabupaten Tanah Datar adalah keberhasilan Golkar dalam mempertahankan tokoh-tokoh strategis hingga saat ini. Figur ataupun tokoh berpengaruh yang berada dalam lingkaran Golkar berperan besar dalam dominasi politik Golkar di kabupaten Tanah Datar yang berlanjut hingga era reformasi. Dapat disimpulkan bahwa Golkar di Kabupaten Tanah Datar adalah Partai Figur. Simpati ataupun identifikasi kepartaian masyarakat di Kabupaten Tanah Datar dimulai dari meneladani figur partai. Jadi, semakin banyak figur yang berafiliasi dengan partai, maka akan semakin banyak pula masyarakat yang nantinya akan dijadikan klien.

Kemampuan partai dalam membangun jaringan dengan tokoh-tokoh formal maupun tradisional membentuk golkar terus mempertahankan hegemoni sejak era reformasi. Afiliasi politik antara partai dengan tokoh dilanjutkan dengan konstruksi pola hubungan yang sifatnya partikularistik (patron klien) oleh tokoh pada masyarakat ditingkatan bawah. Pola ini terjadi secara terus menerus bahkan sudah dilakukan sejak era Orde Baru. Golkar adalah partai figur, hilangnya figur-figur ini bukan tidak mungkin akan menghentikan hegemoni Partai Golkar di Kabupaten Tanah Datar. Salah satu bukti dari dominasi yang kuat dari Partai Golkar di kabupaten Tanah Datar yakni ketika pemilihan kepala daerah tahun 2005, bupati terpilih saat itu yang hanya dicalonkan oleh satu partai saja (Golkar) mampu meraih lebih dari 60 persen suara (Data hasil Pilkada 2005 KPU).

Berdasarkan wawancara yang dilakukan dengan beberapa elit Partai Golkar Kabupaten Tanah Datar, kekuatan partai Golkar terletak pada tokoh partai. Salah satu wawancara dengan wakil DPD Partai Golkar, ketua pemenangan pemilihan umum legislatif PILKADA 2010, Bapak Drs. Hendri N, MM, mengatakan bahwa elektabilitas tinggi yang dimiliki oleh Partai Golkar di Kabupaten Tanah Datar memang berawal dari elit ataupun tokoh yang berafiliasi dengan Partai. Pengalamannya sebagai ketua pemenangan pemilihan umum maupun pemilihan kepala daerah, masyarakat sudah terlanjur simpati dengan tokoh-tokoh ini, karena tokoh partai pada umumnya memiliki social capital yang tinggi sehingga mudah berbaur dan diterima oleh masyarakat. Ikatan ini dibangun dalam jangka panjang, bukan beberapa bulan menjelang pemilu saja. 
"ikatan yang kita bangun dengan masyarakat itu sifatnya jangka panjang, sudah jauh-jauh hari kita bangun, jadi ikatan ini memiliki wilayah rasa sehingga masyarakat tahu, kita memberikan bantuan, menghadiri acara masyarakat tidak beberapa saat sebelum pemilu saja" (Wawancara dengan Tokoh Golkar, Drs. Hendri N, MM, Agustus 2014)

Dari hasil wawancara tersebut, simpati masyarakat harus dengan modal sosial yang tinggi. Dengan hubungan yang sifatnya jangka panjang ini, masyarakat tidak akan pragmatis dalam menentukan pilihan walaupun menjelang pemilihan umum banyak calegcaleg dari Partai lain yang memberikan sesuatu kepada mereka.

"Hubungan saya dengan orang Golkar sangat erat, dia sering bantu disini. Saya sebagai ketua pemuda juga leluasa apabila kita mengadakan acara, yang bantu pasti dari Golkar, itu tiap tahun, tidak menjelang pemilu saja. Ada memang dari partaipartai lain, akan tetapi mereka ini aktif menjelang pemilu saja, kita sebagai orang yang diberi ya terima saja, tetapi tidak pilihan saya tetap Golkar" (Wawancara dengan ketua pemuda Nagari simpuruik, David pada Agustus 2014)

Dari hasil wawancara, inti hubungan yang dibangun oleh elit-elit Golkar bersifat jangka panjang. Tokoh politik Golkar membangun hubungan jangka panjang dengan tokoh-tokoh seperti wali nagari maupun penghulu adat sebagai elit tradisional di nagari. Tokoh-tokoh juga membangun hubungan jangka panjang dengan masyarakat tingkat bawah. Dalam hal ini terjadi hubungan patron klien antara elit dengan elit dibawahnya, dilanjutkan dengan elit dengan masyarakat tingkat grassroot. Jadi, hal tersebut terjadi secara berkelanjutan di Kabupaten Tanah Datar, yang membuat Golkar berkuasa sebagai Partai figur.

\section{Kesimpulan}

Sejak pemilihan umum legislatif tahun 2004, Golkar selalu mendominasi di Kabupaten Tanah Datar. Kemenangan tiga kali berturut-turut selalu didapatkan ketika munculnya partai baru yang memang memiliki elektabilitas tinggi secara Nasional. Namun untuk tingkat Kabupaten Tanah Datar, belum ada partai lain yang mampu menggeser Golkar dari posisi puncak. Golkar merupakan pemain lama yang mendominasi sejak era Orde Baru di Kabupaten Tanah Datar.

Dalam kemenangan dan dominasi Partai Golkar di Kabupaten Tanah Datar, positioning politik yang dilakukan oleh Partai Golkar maupun jaringan patron klien yang telah terbentuk sejak era orde baru sangat berperan penting. Jaringan ketokohan dari kaderkader Golkar terbentuk sampai ke tingkat Nagari dan lembaga-lembaga adat di Kabupaten Tanah Datar. Masyarakat Nagari di Kabupaten Tanah Datar yang mayoritas bekerja sebagai petani juga menjadi faktor kuatnya pengaruh sistem patron klien di Kabupaten Tanah Datar. Data membuktikan tokoh-tokoh penting di Nagari seperti Wali Nagari, Ketua KAN dan hingga ketua LKAAM tidak luput dari jaringan ketokohan Partai Gokar di Kabupaten Tanah Datar.

Selain jaringan ketokohan, kualitas, modal sosial maupun finansial yang dimiliki oleh tokoh-tokoh atau kader Golkar juga merupakan faktor penentu dan penarik simpati masyarakat pendukung terhadap Partai Golkar. Tokoh-tokoh Golkar di Kabupaten Tanah Datar juga mempunyai popularitas di tengah-tengah masyarakat, mulai dari budayawan, guru silat, tokoh agama atau alim ulama, dan niniak mamak. Tercatat tokoh-tokoh Golkar dianggap mampu menyesuaikan diri dan disenangi masyarakat. Hal tersebut tidak bisa dilepaskan dari sistem rekrutmen dan regenerasi kader-kader yang sukses di tubuh Partai Golkar Kabupaten Tanah Datar.

\section{Daftar Pustaka}

Alkhudri, A. T. (2014). Kepemimpinan Elit Lokal di Pedesaan Pada Era Desentralisasi. Ilmu Sosial, 1(1), 120-125.

Asfar, M. (2004). Pemilu dan Perilaku Memilih 1955-2004. Surabaya: Pustaka Utama.

Budiarjo, M. (2008). Dasar-Dasar Ilmu Politik. Jakarta: Gramedia Pustaka Utama. 
Burke, P. (2001). Sejarah dan Teori Sosial. Surakarta: Buku Obor.

Ember, C. R., \& Ember, M. (2001). Countries and Their Cultures. New York: Columbia University Press.

Firdaus, F. (2013). Parade Iklan Politik di Tahun Politik: Polarisasi Penggunaan Iklan Politik Untuk Membangun Citra Menuju Pemilu 2014. Turast: Jurnal Penelitian Dan Pengabdian, 1(1), 81-94.

Firmanzah. (2008). Mengelola Partai Politik; Komunikasi dan Positioning, Ideologi Politik dan Era Demokrasi. Jakarta: Yayaysan Obor Indonesia.

Foster, R. J. (1990). Countries and Their Cultures. Malang: Gandung Mas.

Hadari, N. (1995). Metode Penelitian Bidang Sosial. Yogyakarta: Gajah Mada University Press.

Jones, P. (2003). Pengantar Teori-Teori Sosial. Jakarta: LP3ES.

Kurniadi, P. (2012). Perilaku Elit Lokal Pada Pemilukada Kota Tanjung Pinang Tahun 2012 (Studi Kasus di Kelurahan Sei-Jang Kecamatan Bukit Bestari). JIEB.

Misrina, M. (2010). Metamorfosis Faksionalisme Internal Partai Golkar di Maluku Utara pada Pilkada 2007. Jurnal Studi Pemerintahan, 1(1), 79-96. https://doi.org/10.18196/jgp.2010.0005

Nugroho, A. A., Dua, M., Ujan, A. A., Sihotang, K., Rima, F., Ristiyantoro, ... Kushendrawati., M. S. (2011). Etika Komunikasi Politik. Jakarta: Universitas Indonesia Press.

Scott, J. C. (1972). Perlawanan Kaum Tani. Jakarta: Yayasan Obor Indonesia.

Surbakti, A. S. I. (2016). Peran Elit Lokal Partai Golkar dalam Pemenangan Pileg 2014 Kabupaten Langkat. Jurnal POLITEIA, 8(1), 25-32. 